\title{
Abbreviations and Textual Note
}

AI Paul de Man, Aesthetic Ideology

AR Paul de Man, Allegories of Reading: Figural Language in Rousseau, Nietzsche, Rilke, and Proust

B Jacques Derrida, "Biodegradables: Seven Diary Fragments"

BI Paul de Man, Blindness and Insight: Essays in the Rhetoric of Contemporary Criticism, 2nd edition

EPS Gilles Deleuze, Expressionism in Philosophy: Spinoza

D Jacques Derrida, Dissemination

G Jacques Derrida, Of Grammatology

M Jacques Derrida, Memoires for Paul de Man

OCR Jean-Jacques Rousseau, Oeuvres complètes

R Werner Hamacher, Neil Hertz, and Thomas Keenan, eds., Responses: On Paul de Man's Wartime Journalism

RDR Lindsay Waters and Wlad Godzich, eds., Reading de Man Reading

RE Ronald de Sousa, The Rationality of Emotion

RR Paul de Man, The Rhetoric of Romanticism

S Gilles Deleuze, Spinoza: Practical Philosophy

SP Jacques Derrida, Speech and Phenomena

TP Gilles Deleuze and Félix Guattari, A Thousand Plateaus

WD Jacques Derrida, Writing and Difference

YFS Peter Brooks, Shoshana Felman, and J. Hillis Miller, eds., Yale French Studies 69 [The Lesson of Paul de Man]

Dates that appear in parentheses in the text refer to publication of the editions cited; first publication dates, where these differ, appear in brackets.

Within citations, spelling and italicization of words in languages other than the home language of the texts have been regularized. 
